\title{
Determining dynamics of the Kara Sea coasts using remote sensing and UAV data: A case study
}

\author{
A. V. Novikova ${ }^{1}$, A. P. Vergun ${ }^{1}$, E. A. Zelenin ${ }^{2}$, A. V. Baranskaya ${ }^{1}$, and S. A. Ogorodov ${ }^{1}$ \\ Received 31 August 2020; accepted 7 October 2020; published 3 June 2021.
}

Studies of Arctic coasts are of great importance given their active dynamics with the tendency to retreat, especially in the last decades under the conditions of global climate warming and enhanced human impact. Here, we present the results of the first surveys of the Kara Sea coasts with use of such new technique as unmanned aerial vehicles (UAVs). Land surveys using DJI Phantom 4 PRO drone were conducted at two key sites: the Yamal coast of Baydaratskaya Bay in the area of the Bovanenkovo-Ukhta gas pipeline crossing (western Kara Sea) in 2018, and the western coast of Taymyr peninsula in the area of Dikson settlement, Lemberova Bay (eastern Kara Sea) in 2019. The imagery and DEMs built based on the UAV survey data were compared to earlier satellite imagery and ArcticDEMs that allowed estimation of coastal dynamics for several periods. Since the 1960s, coasts of the key areas had relatively slow retreat $(0.4 \mathrm{~m} / \mathrm{yr}$ for the Yamal area and $0.1 \mathrm{~m} / \mathrm{yr}$ for the Taymyr area) compared to other sites of the Kara Sea and the Arctic in general. At the same time, there were high erosion rates at separate segments in certain periods: they reached $2 \mathrm{~m} / \mathrm{yr}$ at erosional coastal segments with ice wedge outcrops, and up to $10 \mathrm{~m} / \mathrm{yr}$ at low accumulative coasts in the area of gas facilities in the period of their construction. KEYWORDS: Arctic coasts; Kara Sea; UAVs; remote sensing; coastal erosion.

Citation: Novikova, A. V., A. P. Vergun, E. A. Zelenin, A. V. Baranskaya, and S. A. Ogorodov (2021), Determining dynamics of the Kara Sea coasts using remote sensing and UAV data: A case study, Russ. J. Earth. Sci., 21, ES3004, doi:10.2205/2020ES000743.

\section{Introduction}

Arctic coasts composed of frozen deposits are highly dynamic and retreat with an average rate of $0.5 \mathrm{~m} / \mathrm{yr}$ [Lantuit et al., 2012]. In the last decades, retreat of the erosional coasts has accelerated; in addition, previously stable or accretion coasts have started to retreat in some locations [Farquharson et al., 2018. Irrgang et al., 2018. Jones et al., 2009.

\footnotetext{
${ }^{1}$ Geography Faculty, Lomonosov Moscow State University, Moscow, Russia

${ }^{2}$ Geological Institute, Russian Academy of Science, Moscow, Russia

Copyright 2021 by the Geophysical Center RAS. http://rjes.wdcb.ru/doi/2020ES000743-res.html
}

Mars and Houseknecht, 2007; Novikova et al., 2018, Romanenko et al., 2015. Such patterns are apparently driven by the rapid global climate warming, especially strong in the Arctic region (IPCC Special Report on the Ocean and Cryosphere in a Changing Climate, 2019, https://www.ipcc.ch/srocc/, and the previous IPCC reports). At some sites, they are related to the beginning of the active land development [Belova et al., 2020, Novikova et al., 2018, Ogorodov, 2005.

For studies of the Arctic coasts, which are vast, remote and hard to access for repeated fieldwork, remote sensing techniques are widely used. The most common is application of multitemporal space and aerial imagery [Grosse et al., 2005. Günther et al.,2015, Kizyakov et al., 2013, Lantuit et al.,2011. 


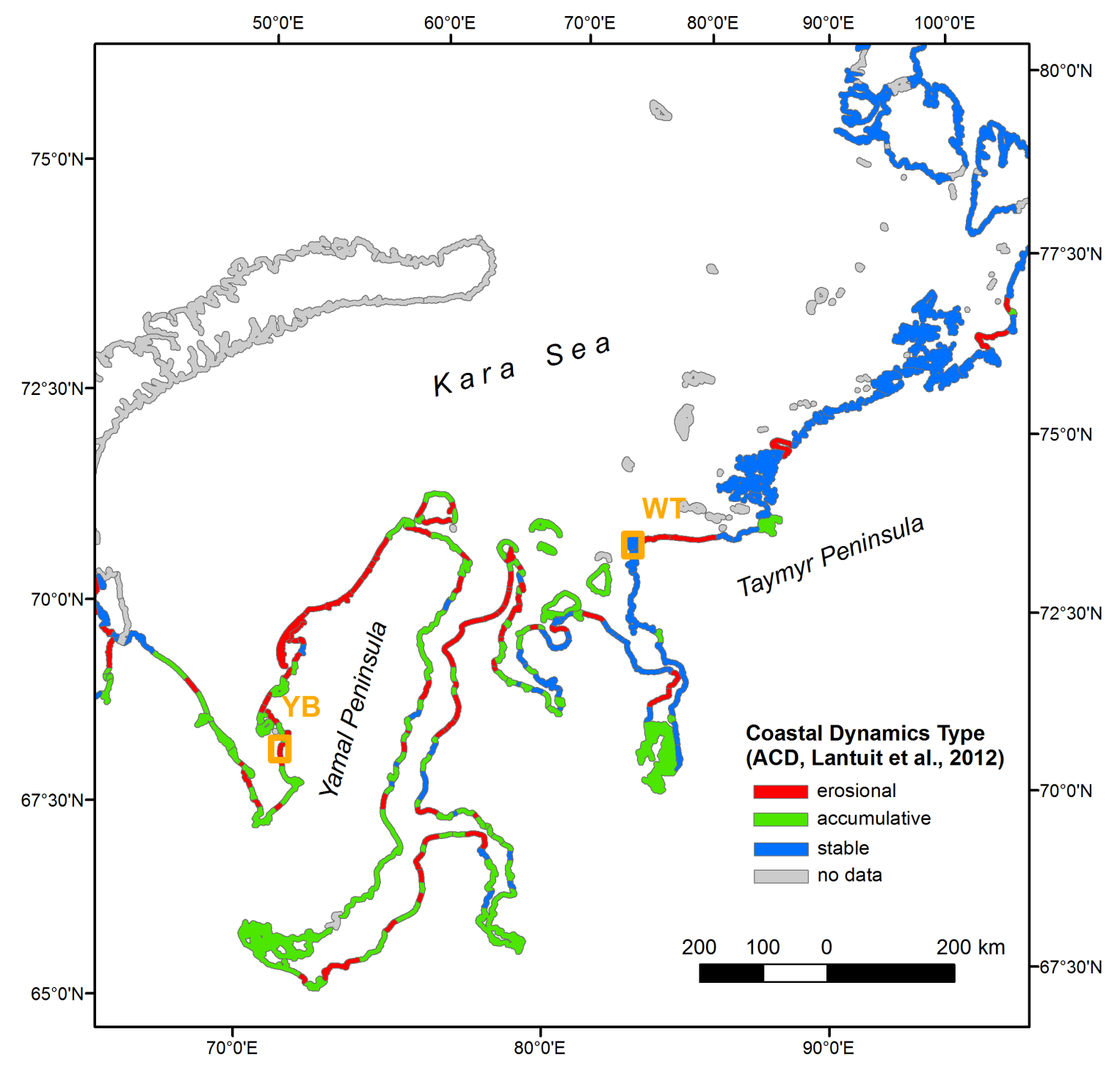

Figure 1. Key sites: YB - Yamal coast of Baydaratskaya Bay, Western Yamal, WT - Western Taymyr, Lemberova Bay.

Mars and Houseknecht, 2007, Pizhankova and Dobrynina, 2010. In the recent years, unmanned aerial vehicles (UAVs) appeared and started being actively used for land surveys [Günther et al., 2017, Klemas, 2015. Obu et al., 2016. Application of UAVs made possible to get terrain images with ultra-high spatial resolution (first centimeters), inaccessible by space and aerial surveys. In case of availability of drone and if fieldwork is possible logistically, obtaining the image with UAVs is cheaper than purchasing a satellite image. In addition, UAV surveys can be made several times faster than surveys using a total station or DGPS, and can cover larger areas.
To test the UAV survey technique for the Kara Sea coasts, surveys were conducted at two key sites: the Yamal coast of the Baydaratskaya Bay in 2018, and the western coast of Taymyr in the area of Dixon in 2019 (Figure 1). They were compared to earlier space images (1960s-2010s), which enabled to extend the series of observations to present. The rates of coastal retreat for the different periods were calculated (long-term periods from the 1960s to the 2010s and short-term periods in the late 2010s) for the two key sites, representing the eastern and the western Kara Sea, respectively. Using DEMs built from the UAV surveys and the ArcticDEMs, we calculated dynamics of the topography in 3D for 
the recent period to identify areas of prevailing denudation (lowering of the surface due to erosion) or prevailing accumulation (rise of the surface due to sediment deposition). The main drivers of spatial and temporal variability of coastal dynamics at key sites were suggested.

\section{Study Area}

\section{Geographical Settings}

Located in the western part of the Eurasian shelf of the Arctic Ocean, the Kara Sea has a severe polar maritime climate. The great length of the Kara Sea from the southwest to the northeast leads to significant spatial differences in climatic conditions throughout the year. In the western part, due to the warming effect from the Atlantic Ocean, the climate is milder and warmer than in the eastern part: moving from SW to NE, the average annual air temperature changes from $-7^{\circ}$ to $-15^{\circ}$ [Atlas of the Oceans..., 1980. Winter (period with average daily temperatures below 0?) lasts from 250 (SW) to 310 (NE) days a year, from midSeptember/October to mid-June/early July. The average temperature of the coldest month (January) ranges from $-18^{\circ}$ in the $\mathrm{SW}$ to $-28^{\circ}$ in the NE, the average temperature of the warmest month (July) varies from $+6^{\circ}$ in the $\mathrm{SW}$ to $+1^{\circ}$ in the NE. In winter, winds from the mainland $(\mathrm{S})$ prevail, in summer, they are mostly directed from the sea (NW, N, NE). Summer winds from the sea generate waves, which especially intensively affect the coast in the summer ice-free period. The prevailing $(50 \%)$ wind speed in the summer period is from 3 to $6 \mathrm{~m} / \mathrm{s}$, the frequency of storms is from 10 to $20 \%$. The average annual precipitation in the western part of the Kara Sea (Amderma) is $390 \mathrm{~mm}$; in its eastern part (Dikson) it is $370 \mathrm{~mm}$, most of the precipitation falls in summer-autumn, from June/July to September/October [Atlas of the Oceans..., 1980.

In the last decades, the climate of the region has been changed with the tendency to warming. Shabanova et al. 2018 declare the growth of air thawing and air freezing indexes (on the average 17.3 and 5.7 degree-days per year respectively) within the last 35 years in the Barents-Kara region, as well as an increase of the median value of the ice-free period by about 30 days (43\%).
Harsh climate determines the year-round presence of ice in the Kara Sea. Near the coast, the sea is covered by ice in autumn and winter (from October to May), the duration of the ice-free period ranges from 1.5 months in the NE to 4 months in the SW [Atlas of the Oceans..., 1980]. The temperature of the under-ice water layer is everywhere close to the freezing point of water of a given salinity $\left(-1.5-1.7^{\circ} \mathrm{C}\right)$; in the warmest summer months, water temperature rises above $0^{\circ} \mathrm{C}$ in the shallow southwestern part of the sea [Dobrovolskiy and $Z a$ login, 1982. The height of the tides is $0.5-0.8 \mathrm{~m}$ on average. Waves with a height of $1.5-2.5 \mathrm{~m}$ have the greatest frequency of occurrence, waves of $3 \mathrm{~m}$ and more are observed less often; the greatest wave height reaches $8 \mathrm{~m}$. The strongest waves mostly occur in the southwestern and northwestern parts of the Kara Sea, which are the longest free of ice [Dobrovolskiy and Zalogin, 1982].

The Kara Sea is shallow: more than $80 \%$ of its water area has the depths of less than $200 \mathrm{~m}$, the average depth is $111 \mathrm{~m}$. The southwestern part of the Kara Sea is the shallowest: depths do not exceed $100 \mathrm{~m}$, and the depth of the Baydaratskaya Bay does not exceed $40 \mathrm{~m}$. The coasts are mainly low-lying accumulative plains, only the coasts of the Taimyr Peninsula in some places are abrasionaccumulative and denudation-erosional plains.

At most of the Kara Sea coasts, unlithified quaternary deposits form a continuous cover with a thickness of up to $150-200 \mathrm{~m}$; only in its eastern part (Taymyr Peninsula), Late Paleozoic sedimentary and volcanic rocks compose the coasts [VNIIOkeangeologiya, 2000]. Upper Pleistocene marine, coastal-marine and alluvial-marine (loams and clays, alternating in the section and in plan with sands) and Holocene marine and coastalmarine (mainly loamy and clayey silts, sandy loams, less often - sands) sediments form the topography [GEOS, 1997].

Past severe climate of the Late Pleistocene determined continuous distribution of permafrost. Its thickness depends on the topography levels: from $300 \mathrm{~m}$ within the highest plains, to less than $50 \mathrm{~m}$ within laidas - low coastal surfaces inundated during the highest tides and storm surges [Ershova, 1989. Through taliks (areas without permafrost) are developed under sea bays, large lakes and channels of large rivers [Trofimov et al., 1986]. The average annual temperature of soil at the depth of zero temperature fluctuations is from -2 to $-5^{\circ}$. 
The thickness of the active layer varies from $0.3-0.4$ to $2 \mathrm{~m}$ [GEOS, 1997].

Comparing the key sites at opposite sides of the Kara Sea allows to trace changes in coastal dynamics in different climatic and geologic conditions: Western Yamal is in the western part of the Kara Sea with its milder climate and unlithified deposits with higher ice content and occasional ground ice bodies, while Western Taymyr is in the eastern part of the sea and has much more severe climate conditions and segments of rocky coasts (Figure 1).

\section{Western Yamal, Yamal Coast of Baydaratyskaya Bay}

The key site is a $12 \mathrm{~km}$-section of the Yamal coast of Baydaratskaya Bay between Cape Mutniy in the north and the mouth of Liyakha river in the south, in the area of the underwater crossing of the gas pipeline Bovanenkovo-Ukhta. The gas pipeline and the infrastructure facilities were constructed in 2009-2013; they consist of four gas pipeline strings, two cofferdams near the landfall of the pipeline, Baydaratskaya compressor station, a housing complex, a port at the mouth of Yarayakha river, roads, coastal protection structures, and other facilities.

The site has several topography levels: undulating flatlands of 12-16 $\mathrm{m}$ height in the northern and southern parts, and of 25-30 m height in the southernmost part, presumably of lacustrine-alluvial origin and of Late Pleistocene age, composed of sands or sands with loams or clays in the lower part $[R o-$ manenko, 2011. To the north of the cofferdams, there is a Late Pleistocene/Holocene marine terrace of 6-8 $\mathrm{m}$ height, composed of sand. In the central part, Holocene laida of $2-4 \mathrm{~m}$ height is located; it is composed by sands with pebbles underlain by loams and is separated from the beach by a sandy coastal barrier of up to $2 \mathrm{~m}$ height.

The deposits of high terraces are perennially frozen; relic and modern polygonal-wedge ice occurs [Belova, 2014]. Sands with gravels, pebbles, shells and detritus prevail in beach sediments; in some areas (in the area of Cape Mutniy, the mouth of the Yarayakha River), loams and clays are exposed near the sea level. The width of the beaches ranges from up to $150 \mathrm{~m}$ immediately north of the mouth of Yarayakha river to less than $10 \mathrm{~m}$ near Cape Mutniy and at a thermodenudational segment south of Yarayakha.
The coast of the area is protected from the northerly and partly north-westerly winds by the Marresalske Koshki island chain. The longshore sediment flux is directed from the mouth of Yarayakha River northwards to Cape Mutniy, where it fades, forming a wide tidal flat. In the Yakhayakha river delta, sediment migration is bilateral, most of it accumulating on the northern side of the delta, also forming a wide tide flat. Along the coast, offshore bars with a height of about $1 \mathrm{~m}$ form.

The coast at the sections of high terraces is abrasional (eroded by sea waves), sometimes abrasionalthermodenudational (e.g., near Cape Mutniy, (Figure 2) and to the south of Yarayakha); in the central part, at the laida to the north of Yarayakha, it is accumulative.

At the Yamal key site, natural coastal processes were disturbed as a result of the gas pipeline construction. Analysis of the state and dynamics of the coast before and after the construction in 2009 2013 enable to reveal possible human-induced pressure on coastal landscapes. Repeated monitoring of the coastal dynamics started back in 1988, as total station and DGPS surveys along the profiles of the monitoring network. Extensive data on geological, permafrost, geomorphological conditions are also available [Kamalov et al., 2006, Melnikov and Spesivtsev, 1995, GEOS, 1997, Novikova et al., 2018. Ogorodov et al., 2016, Romanenko et al., 2009.

\section{Western Taymyr, Dikson Area, Lemberova Bay}

The Western Taymyr key site is a 3 -km section of the coast in the southern part of Lemberova Bay (about $15 \mathrm{~km}$ to the south from Dikson urbantype settlement). The coasts have a steep abrasion bluff of 10-15 m height, composed by sands interbedded with loams and sandy loams, occasionally with gravel and small pebbles, presumably of marine or alluvial-marine origin. In the northern part of the site, the coast is abrasional, but has a fading bluff (Figure 3): it is gently-sloping, mostly uncovered by grass, sporadic traces of erosion are found in its lower part only; the beach is pebbly, $10-15 \mathrm{~m}$ wide. In the central part of the site the coastal bluff is steep and has an abrasionalthermodenudational appearance, the beach is pebbly, 5-10 m wide (Figure 3). To the south, the coast lowers to a height of $\sim 5 \mathrm{~m}$, and is composed of coarser-grained deposits - sand and gravel 


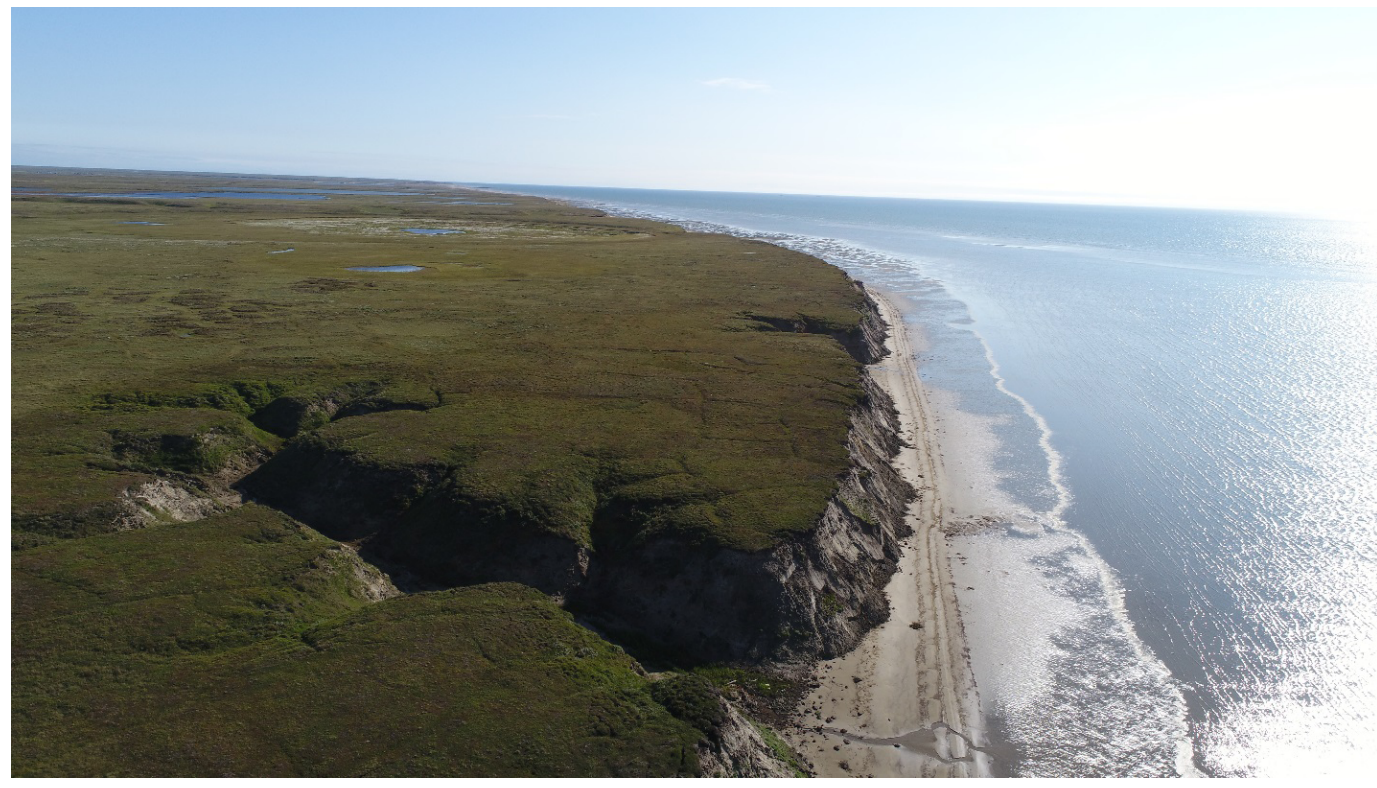

Figure 2. Thermoerosional ravine and abrasion-thermodenudation coastal bluff in the area of cape Mutniy, Western Yamal, photo from the UAV.

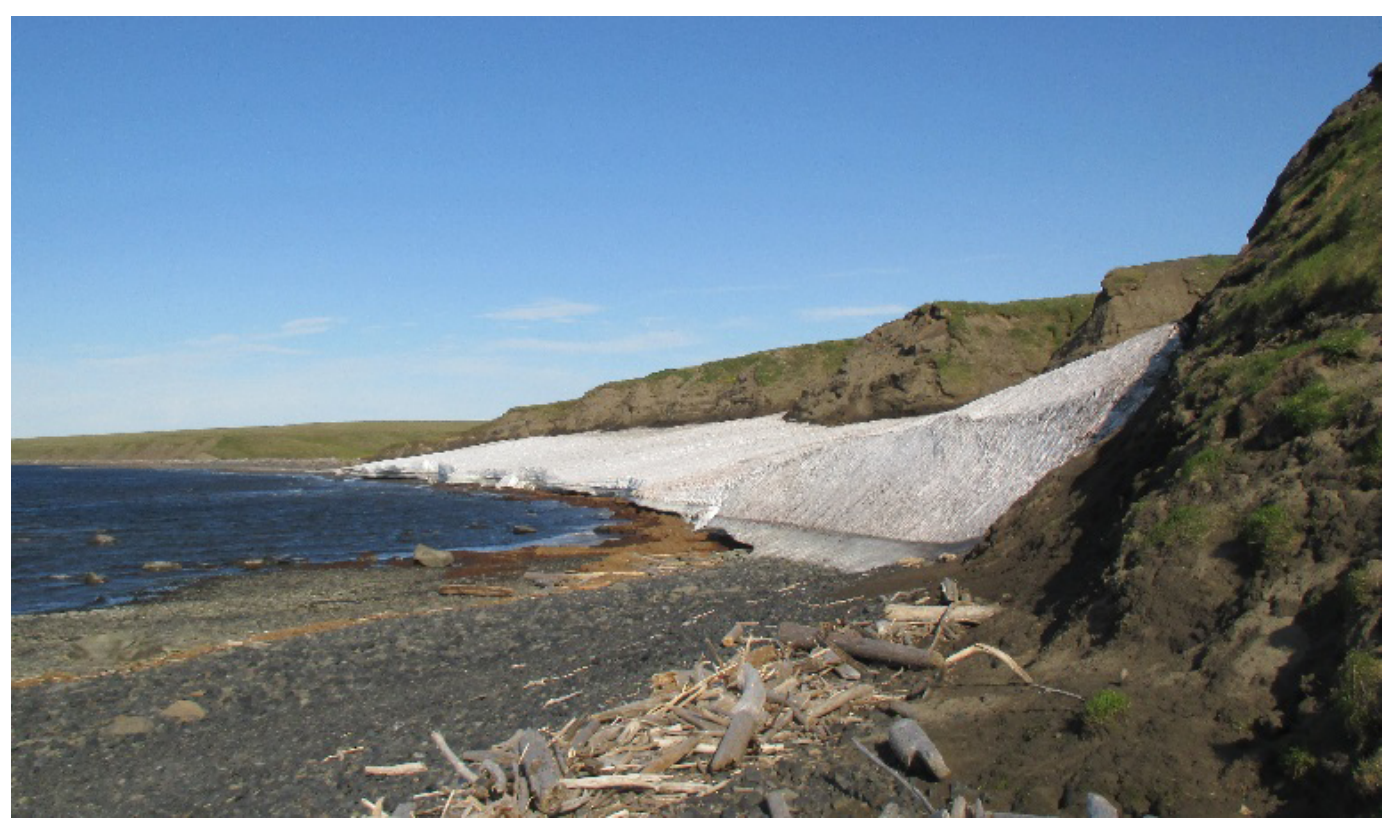

Figure 3. Abrasional-thermodenudational coast of Lemberova Bay, Western Taymyr. In the background abrasion coast with fading bluff. 


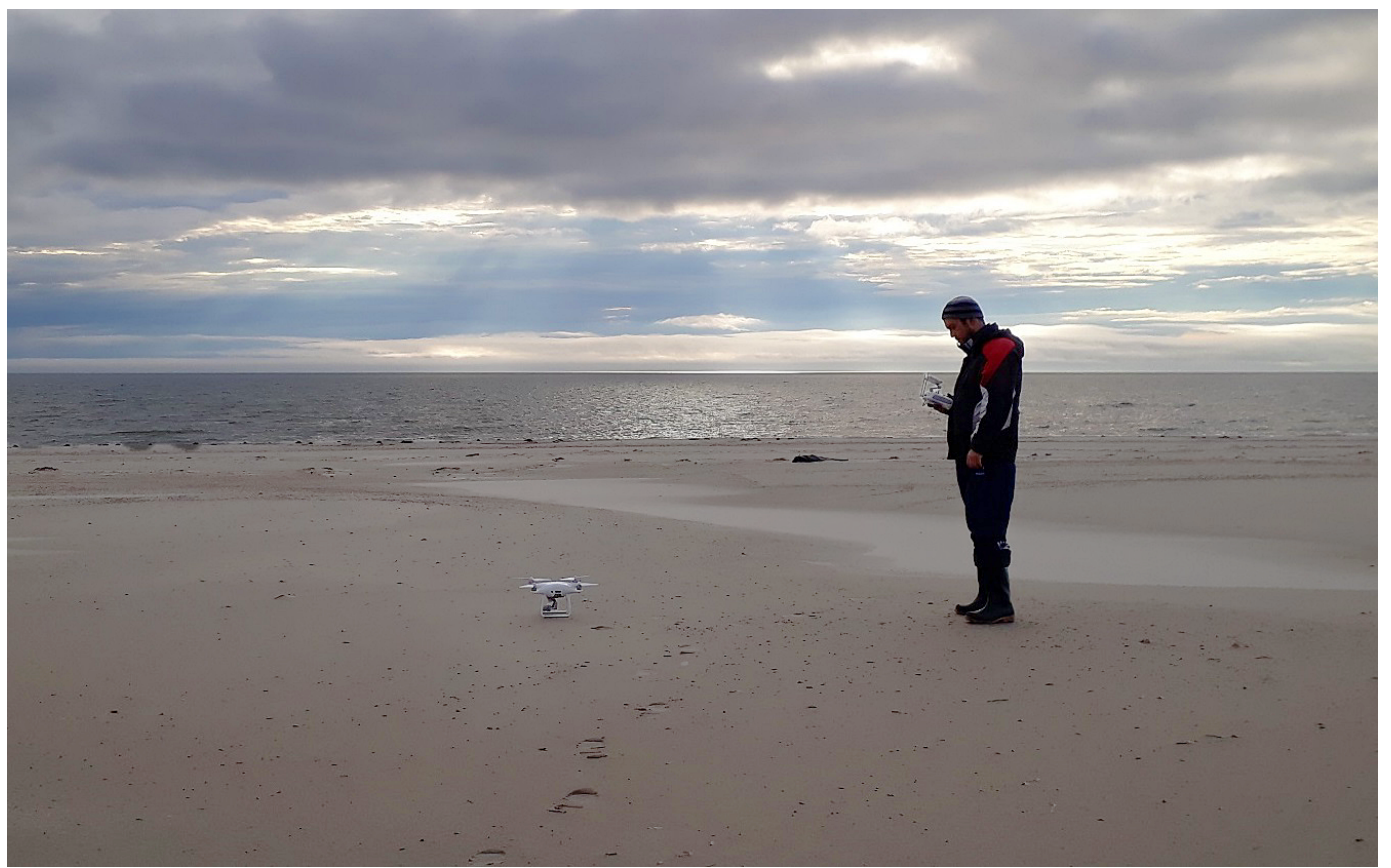

Figure 4. Land survey with DJI Phantom PRO 4 drone at the Yamal coast of Baydaratskaya Bay.

with large pebbles. Further, to the southwest, outside the site, rocky bedrock outcrops at sea level. On small accumulative sections near the mouths of rivers and streams, there are low surfaces of alluvial origin, composed mainly of loamy deposits; the height of the coastal scarp is up to $1 \mathrm{~m}$; traces of erosion are observed, sandy beaches are 15-20 m wide.

On the western coast of Taymyr, previous studies were carried out in the area of the Dikson (Severo-Vostochnaya Bay and Yuzhnaya Bay) and at Cape Sopochnaya Karga: sedimental sections were described with special attention to the structure of ground ice [Oblogov, 2016, Streletskaya et al., 2009. Rates of retreat of thermo-abrasion coasts, composed of highly icy deposits of the ice complex, was roughly estimated as up to $3-7 \mathrm{~m} / \mathrm{yr}$ [Streletskaya et al., 2009]. However, direct measurements of the coastal retreat rates in Lemberova Bay have not been carried out before, as well as high-precision multitemporal coastal dynamics analysis at western Taymyr in general.

\section{Materials and Methods}

\section{Fieldwork}

During the expeditions in August 2018 (Yamal) and in July-August 2019 (Taymyr), UAV surveys were conducted. They were made with DJI Phantom PRO 4 quadcopter (Figure 4), in manual mode, in nadir, at an altitude of $100 \mathrm{~m}$, in two reaches (round trip), by sections of $\sim 1 \mathrm{~km}$ length, with 60-80\% overlap enabling to create a stereo model, and a frame frequency of 30 frames per minute. The total amount of photographs is 3486 shots at the Yamal coast (area of $3.6 \mathrm{~km}^{2}$ ), and 276 shots at the Taymyr coast (area of $0.9 \mathrm{~km}^{2}$ ).

The accuracy of the absolute georeferencing of the images obtained by a standard quadcopter is about $5 \mathrm{~m}$ (positioning accuracy of the GPS of the drone). If possible, for more detailed georeferencing, a simultaneous survey of ground control points (GCPs) is necessary, using, for example, a total station or DGPS. This enables to improve the accuracy of the absolute georeferencing up to $0.05 \mathrm{~m}$. Such survey was conducted at one of the key sites - Yamal coast. Here, a survey of the network of the index marks was carried out using Javad Sigma DGPS receivers with an external GRANT J3T antenna in RTK mode (accuracy of about $3 \mathrm{~cm}$ laterally and $4.5 \mathrm{~cm}$ vertically). As a system of primary survey control served a network of points of the state geodetic network (GSN), the altitude system - Baltic BS-77, the transition from ellipsoidal heights of the satellite system to orthometric heights of the GSN was made using the EGM 2008 geoid model. 

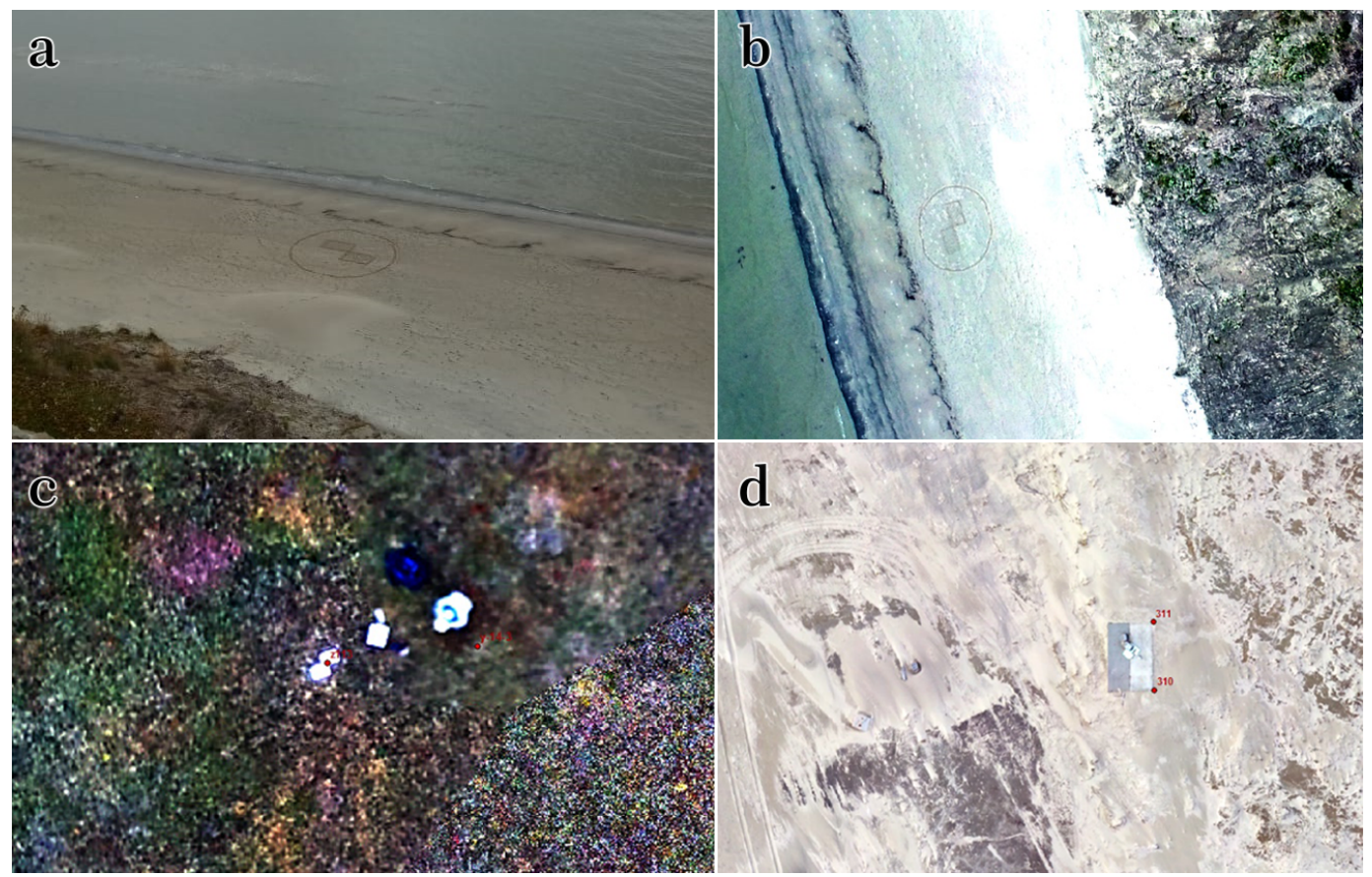

Figure 5. Index marks: painted on the beach on the ground (a) and in the image (b), paper marks in the image (c) corners of concrete slabs in the image (d).

In the case of the Yamal site, the optimal solution for the georeferencing was the installation of two markers - one on the beach and one on the terrace, for every $200-300 \mathrm{~m}$ of the shore. It creates a network consisting of rectangles, with long sides parallel to the coastline, the marks being vertices. This scheme enables the most correct georeferencing of filming materials to the terrain and ensures the most accurate determination of heights at various levels - on the beach and on the terrace. We used sheets of white paper, fixed on the surface to form a distinct angle, as marks, alternative marks were natural or man-made objects with clear shapes (corners of buildings, intersections of roads, corners of concrete slabs, pallets, logs, boards, etc.). For beaches, marks were drawn on the sand (Figure 5).

\section{Processing of the UAV Survey Data and Construction of DEMs and Orthomosaics}

Based on the results of the UAV survey, digital elevation models (DEM) and orthophotomaps (or ortomosaics-aerial/space images on a geodetic basis, transformed from a central projection into an orthogonal projection using orthorectification) were created in Agisoft PHOTOSCAN software.
The technique for processing UAV survey results is described in detail in [Eltner, 2015. Goncalves and Henriques, 2015, Koci et al., 2017; Smith et al., 2015, etc.]. The algorithm includes identification and comparison of elements in the images, implementation of algorithms for adjusting the nodal points to assess three-dimensional geometry, linear similarity transformation for scaling and referencing the point cloud and its optimization (in Agisoft PHOTOSCAN: Workflow Align Photos). Geodetic coordinates of the markers obtained during fieldwork were set manually at this stage. Implementation of algorithms for matching stereo images enables to build a dense three-dimensional point cloud (Workflow - Build Dense Cloud). Based on it, a DEM (Workflow - Build DEM) and an orthomosaic (Workflow Build Orthomosaic) are built. As a result, ultrahigh-resolution DEMs (resolution up to $5.6 \mathrm{~cm}$ ) and orthophotoplans (resolution up to $2.8 \mathrm{~cm}$ ) were obtained.

\section{Comparison of the UAV Survey Data With Instrumental Measurements and ArcticDEM}

For the Yamal study area, a comparison of the horizontal and vertical coordinates from the UAV 


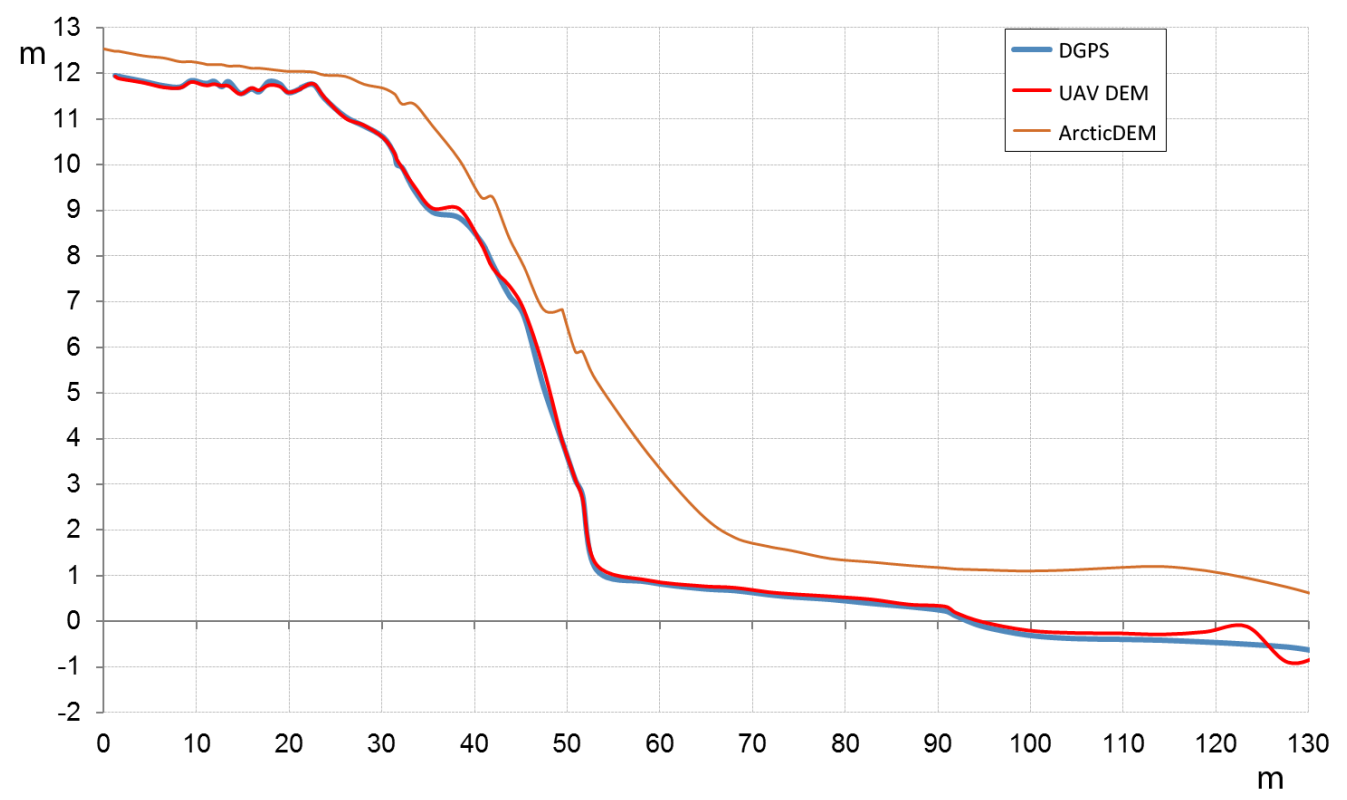

Figure 6. Comparing the surface from the UAV DEM (2018), DGPS survey (2018) and ArcticDEM (2016) along the 70th transect of the Yamal coast.

survey and from the DGPS survey was carried out for verification. It showed high convergence: deviations do not exceed $\pm 0.4 \mathrm{~m}$ (Figure 6). The greatest differences were noted on the surface of the coastal bluff and on the seaward part of the tidal flat. They apparently result from distortions behind the relief and the absence of reference points in these parts of the coastal zone (the marks were placed on the surface of the terrace and beach), or from water reflections on tidal flats. The surface of the UAV DEM, as a rule, is located 0.05-0.1 m higher than the surface according to the DGPS survey, which is most likely caused by the fact that the drone captures not the topography, but the tundra vegetation surface. Extraction of heights from the DEM at the DGPS survey points for their comparison was carried out in ArcGIS software (ESRI Inc., Redlands, CA, USA). Analysis of the obtained data was carried out in ArcGIS and Excel.

Heights obtained from the UAV survey during the expedition of 2018 for Yamal were compared with ArcticDEM altitudes from 2016 (Figure 6). ArcticDEM is a global DEM for the Arctic region, created by Polar Geospatial Center of University of Minnesota's College of Science and Engineering and is in open access (https://www.pgc.umn.edu/ data/arcticdem/). It was built based on stereopairs of DigitalGlobe images, and has a spatial resolution of 5-2 m and vertical accuracy of $0.3 \mathrm{~m}$ [Dai et al., 2017. This accuracy is significantly lower than the accuracy of a DEM built from a drone survey $(5.6 \mathrm{~cm})$, which partly explains the significant discrepancies in height (Figure 6). However, even with such accuracy, general conclusions about the structure and dynamics of the coastal zone and its trends can be made. Along the whole segments, retreat of the top and of the slope of the coastal bluff and a decrease in the absolute height of the terrace and beach surface for the period 2016-2018 were observed. Significant discrepancies in the ArcticDEM heights can be associated, for example, with the presence of snowfields or cloud cover on the image used to build ArcticDEM. For Taymyr, results of fieldwork in 2019 were compared to ArcticDEM, constructed from Digital Globe imagery of 2015, with similar discrepancies. The use of ArcticDEM is therefore possible for studies of topography dynamics at relatively small scales. Improvement of the ArcticDEM horizontal and vertical referencing is also necessary. 
Table 1. Remote Sensing Data for the Key Sites of the Study

\begin{tabular}{lccc}
\hline Sensor & Date & Resolution, $\mathrm{m}$ & Accuracy of referencing, m \\
\hline \multicolumn{4}{c}{ Yamal coast of Baydaratskaya Bay, Western Yamal } \\
\hline Corona KH-4 & 21.08 .1968 & 2.6 & 5.2 \\
WorldView-3 & 21.06 .2016 & 0.3 & 0.4 \\
UAV & 18.08 .2018 & 0.06 & 0.05 \\
\hline \multicolumn{4}{c}{ Lemberova Bay, Western Taymyr } \\
\hline Corona KH-4 & & \\
WorldViev-2 & 22.07 .1965 & 2.7 & 5.4 \\
UAV & 17.07 .2015 & 0.5 & 5.0 \\
\hline
\end{tabular}

\section{Interpretation of the Images and Calculation the Rates of Coastal Retreat/Advance}

Images obtained from the UAV surveys were compared with the satellite images of previous years: declassified Corona KH-4 images from the 1960s, with the spatial resolution of $2.7 \mathrm{~m}$, and recent WorldView images from the 2010s, with the spatial resolution of $0.3-0.5 \mathrm{~m}$ (Table 1). In addition, DEMs from UAV imagery and ArcticDEM (https://www.pgc.umn.edu/data/arcticdem/) were compared, which made it possible to identify areas of predominant denudation and areas of predominant accumulation of deposits. The images for the Yamal area were processed (pan-sharpening, ortho-rectification) and referenced using a network of GCPs captured by DGPS receivers (for a detailed description, see [Novikova et al., 2018]). For the Taymyr area, due to the lack of a set of DGPS GCPs, the image referencing is less accurate (Table 1) and the uncertainties of the obtained data are higher, however, for long-term periods, they generally reflect real patterns of coastal dynamics. For the WV-2 image, orthorectification and pansharpening were performed, the Corona image was linked to the WV-2 image using the Spline function in ArcGIS with a large set of referencing points.

The shoreline was traced on the images with pixel accuracy in ArcGIS (ESRI Inc., Redlands, CA, USA). The top of coastal bluff was traced as a shoreline on erosional segments with wellexpressed bluffs; on accumulative coasts, the dense vegetation boundary (as the upper limit of the wave impact) was marked as the shoreline. In some cases, identification of coastline on the aerospace images, and even in field, may be challenging and controversial, for example, in case when the coastal bluff and the coastal part of the terrace are covered with sandy deposits, or in case of an unclear dense vegetation boundary on accumulative coasts. On the low resolution black and white images (Corona or similar), the sandy shore and bluff may be bleached. The use of detailed images from UAVs can be helpful to more precisely determine the shoreline position.

To calculate the rates of coastline movements we used an ArcGIS extension, Digital Shoreline Analysis System, DSAS [Thieler et al., 2009]. It automatically builds transects normal to the general direction of the coastline (baseline) with an optional spacing along the baseline (in our case, $50 \mathrm{~m}$ ). A date is set for each shoreline. For each transect, the rate for a definite time period is calculated as the distance between the two respective coastlines (end point rates - EPR); some other statistics are also calculated (linear regression, weighted regression, trend, and others). The program also allows visualization of the obtained results.

The DEMs retrieved from the UAV surveys were compared to the ArcticDEM of 2016 for the Yamal site and of 2015 for the Taymyr site to create maps of surface dynamics of these areas during 2016-2018 (Yamal) and 2015-2019 (Taymyr), respectively. Since ArcticDEM has a resolution of 
up to $2 \mathrm{~m}$ and can have a referencing error up to $5 \mathrm{~m}$, comparison with the UAV DEM is complicated. Although the data on the dynamics of the relief have significant uncertainties, it allows to estimate the general trends and patterns of the dynamics of these coasts.

\section{Uncertainty Assessment}

Calculating the uncertainties of the shoreline retreat/advance was made taking into account the following sources of potential image distortion:

1. Spatial resolution $\left(\delta_{s}\right)$,

2. Accuracy of georeferencing $\left(\delta_{r}\right)$,

3. Topography-induced uncertainty $\left(\delta_{t}\right)$.

The first uncertainty $\delta_{s}$ shows how accurately the shoreline can be traced along the raster; it was assumed equal to $1 / 2$ of the spatial resolution of the image. The georeferencing uncertainty $\delta_{r}$ was calculated as the mean of the root mean square errors of all referencing points (total RMSE in the link table in ArcGIS). The topography-induced uncertainty $\left(\delta_{t}\right)$ is caused by relief-induced horizontal displacement. It is calculated as

$$
\delta_{t}=\operatorname{tg} \alpha \times h,
$$

where $\alpha$ is the tilt angle of the spacecraft and $h$ is the maximum relative height at the territory. It can be excluded from the total uncertainty calculation in case of performing the orthorectification of the image, what we did.

The total error of the position of the coastline of one image was calculated as an overall error as independent sources:

$$
\delta_{x}=\sqrt{\delta_{0 t}^{2}+\delta_{r}^{2}+\delta_{s}^{2}} .
$$

The accuracy of the linear rate of coastal retreat between the positions of the shoreline $x_{1}$ and $x_{2}$ for the time period between $t_{1}$ and $t_{2}$ was calculated as:

$$
\delta_{r}=\frac{\sqrt{\delta x_{1}^{2}+\delta x_{2}^{2}}}{t_{1}-t_{2}} .
$$

The calculated uncertainties of the rates of retreat for different time periods range from 0.11 to $1.77 \mathrm{~m}$ (Table 2), the data for the Yamal key site are more precise than for the Taymyr key site.

\section{Results}

Based on the data of UAV surveys of the key sites, we created very high resolution orthomosaics (spatial resolution up to $2.8 \mathrm{~cm}$ ) and DEMs (up to $5.6 \mathrm{~cm}$ ), and calculated the rates of coastal retreat for several periods from the 1960s to present (to 2018 at Yamal site and 2019 at Taymyr site).

\section{Yamal Key Site}

In 2016-2018, most of the coastline retreated (115 of 200 transects, $5.8 \mathrm{~km}$ of 10, Figure 7). The average rate of retreat amounted $1.3 \mathrm{~m} / \mathrm{yr}$, the maximal retreat (up to $10 \mathrm{~m} / \mathrm{yr}$ ) was observed to the south of the cofferdams (Figure 7). A large part of the coastline of the Yamal key site in the area of the laida has been advancing in 2016-2018. Apparently, it is related to the fact that the vegetation cover destroyed during the pipeline construction started to recover and advance seaward. At the same time, some parts of the accumulative coast experienced a retreat as well.

In general, during the whole period of 1968-2018, the whole coast retreated with an annual average for all transections rate of $0.4 \mathrm{~m} / \mathrm{yr}$, for erosional areas, the average rate was equal to $0.5 \mathrm{~m} / \mathrm{yr}$. Maximal rates of retreat were noted on the accumulative segment on the laida between the cofferdams and the port (transects 78-93, Figure 7): 1.5$3 \mathrm{~m} / \mathrm{yr}$. Erosional coasts retreated most intensively within the area of the low 6-8 $\mathrm{m}$ terrace (transects 141-146, Figure 7) to the north of cofferdams (0.7$0.9 \mathrm{~m} / \mathrm{yr}$ ), and for the abrasion-termodenudation coasts within the medium 12-16 m terrace south of Yarayakha river (transects 55-74, Figure 7, 0.5$0.7 \mathrm{~m} / \mathrm{yr})$ and in the area of Mutny (221-233 transects, $0.4-0.6 \mathrm{~m} / \mathrm{yr}$ ), where the wedge ices were found out.

The average retreat rate for the historical longterm period (1968-2016) was $0.5 \mathrm{~m} / \mathrm{yr}$, while in 2016-2018, on the average, the coast advanced $(+1.3 \mathrm{~m} / \mathrm{yr})$ due to reestablishment of the vegetation cover and the advance of the dense vegetation boundary on the accumulative coast in the vicinity of cofferdams and the port. Considering the dynamics of erosional coasts separately, in 1968-2016 they retreated with an average rate of $0.5 \mathrm{~m} / \mathrm{yr}$, while in 2016-2018, they were eroded with an average rate of $0.6 \mathrm{~m} / \mathrm{yr}$. 
Table 2. Uncertainties of Coastal Retreat-Advance Rates

\begin{tabular}{lccc}
\hline \multicolumn{2}{c}{ Yamal key site } & \multicolumn{2}{c}{ Taymyr key site } \\
\hline Period & Rate uncertainty, m/yr & Period & Rate uncertainty, m/yr \\
\hline $1968-2018$ & 0.11 & $1965-2019$ & 0.15 \\
$1968-2016$ & 0.12 & $1965-2015$ & 0.16 \\
$2016-2018$ & 0.25 & $2015-2019$ & 1.77 \\
\hline
\end{tabular}

Comparison of the 2016 ArcticDEM and the DEM obtained from the UAV survey of 2018 , shows that the areas of the most intensive denudation (lowering of the surface) include the coastward parts of high terraces (in the north near Cape Mutniy - Figure 8, and in the southern part of the area) and at the walls of large thermoerosional ravines. The absolute beach height also decreased in large areas in 2016-2018, which is especially noticeable in the southern part of the area. Accumulation is observed in places on the surface of the laida and on the beach and tidal flat near the Yarayakha river mouth.

\section{Taymyr Key Site}

On the average, in 1965-2019 the coast retreated with a low average rate of $-0.1 \mathrm{~m} / \mathrm{yr}$ in the area of Lemberova Bay. In the recent years, these rates increased significantly: in 1965-2015, the average annual rate was $0.06 \mathrm{~m} / \mathrm{yr}$, while in $2015-2019$, it reached $0.9 \mathrm{~m} / \mathrm{yr}$ Figure 9 ).

Rates of coastal erosion are evenly distributed along the entire segment. The most significant reshaping (with a tendency to retreat) was observed at river mouths: Lemberova and an unnamed river in the south of the site, where the coast retreated by a distance of $30 \mathrm{~m}$ in 54 years $(0.6 \mathrm{~m} / \mathrm{yr})$. The precision of this value is relatively low due to the complexity of determining the coastline position on accumulative coasts, especially river fans with active interseasonal dynamics and the low resolution of the 1965 Corona image. In the north of the area near the mouth of Lemberova river, the coast retreated at a rate of $0.2-0.3 \mathrm{~m} / \mathrm{yr}$.

Comparison of the coastal dynamics for two periods, the long-term 1965-2015 and the short-term modern period 2015-2019 (Figure 9) shows a sig- nificant increase in the coastal retreat in the recent years throughout the entire area (the values are $0.06 \mathrm{~m} / \mathrm{yr}$ and $0.9 \mathrm{~m} / \mathrm{yr}$, respectively). The maximum erosion of the coast took place near a stream mouth on transect 36 (7.6 $\mathrm{m}$ in four years), apparently associated with erosion of a temporal large fan or landslide. However, in 2015-2019, retreat of the coastal bluff at a rate of $0.4-1.0 \mathrm{~m} / \mathrm{yr}$ is observed along the entire Taymyr key site. Besides the fastest retreating erosional coasts, high rates were noted in the central part of the site in the area of abrasional-thermodenidational coasts (Figure 3).

Subtraction of the 2015 ArcticDEM DEM from the 2019 drone DEM (Figure 10) shows the greatest denudation of the coastal bluff and beach in the central and southern parts of the key site, associated with coastal abrasion in this area. It might be also caused by the presence of a snowfield during the survey in 2019 and its absence or much smaller size during the survey in 2015. Erosion is also noted in ravines in the northern part of the area. Weak accumulation took place in small areas near the mouths of the Varavikova river and of the unnamed stream in the south of the site.

\section{Discussion}

\section{Dynamics of the Coasts of the Western and Eastern Sectors of the Kara Sea}

The revealed average long-term retreat rates of the studied coasts are relatively low: $0.4 \mathrm{~m} / \mathrm{yr}$ for the Yamal area and $0.1 \mathrm{~m} / \mathrm{yr}$ for the Taymyr area. They are significantly lower than the average rates of retreat for the Arctic as a whole $(0.5 \mathrm{~m} / \mathrm{yr}$, [Lantuit et al., 2012]) and lower than the average rates 

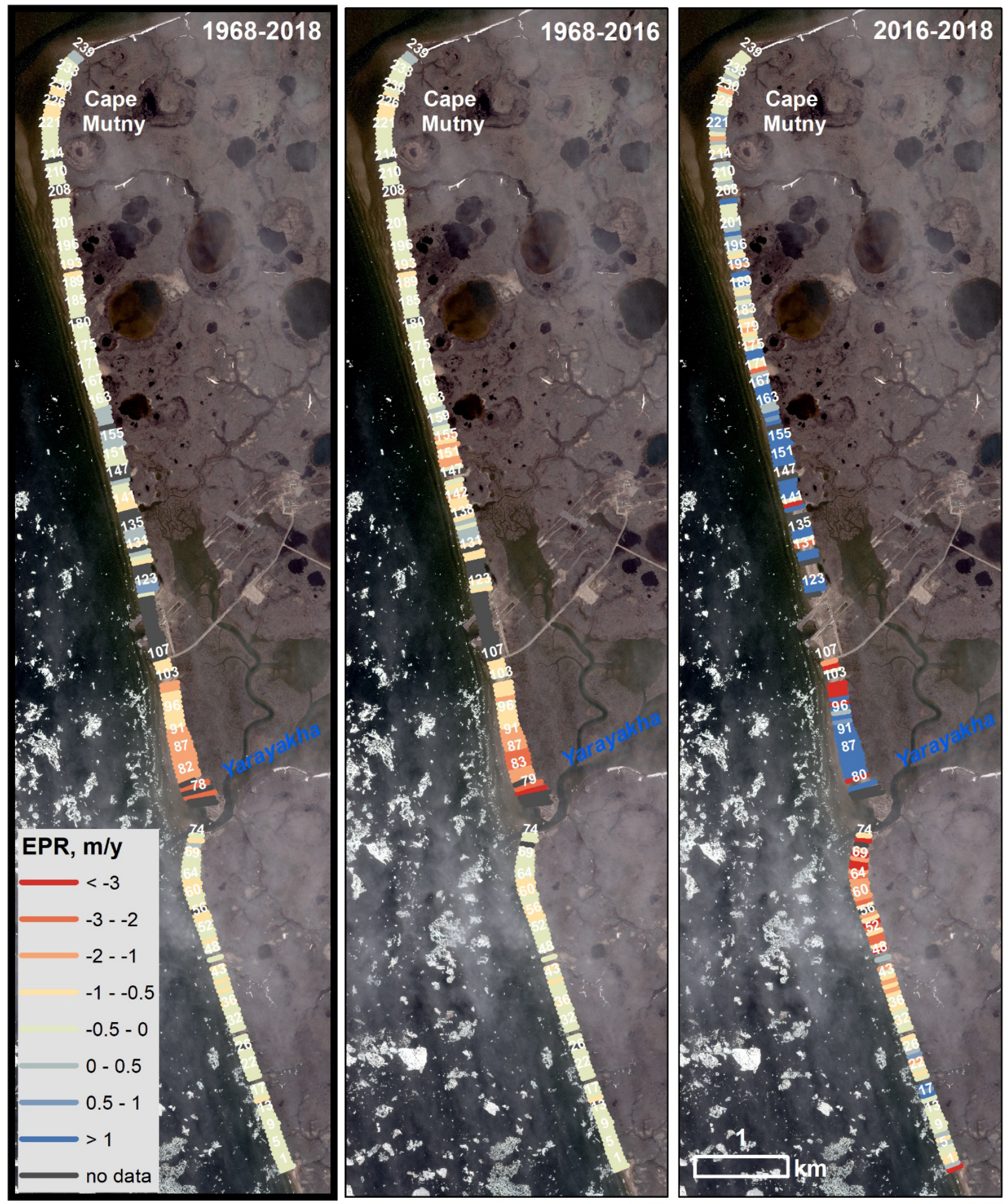

Figure 7. Rates of coastal retreat/advance (EPR) of the Yamal key site. 

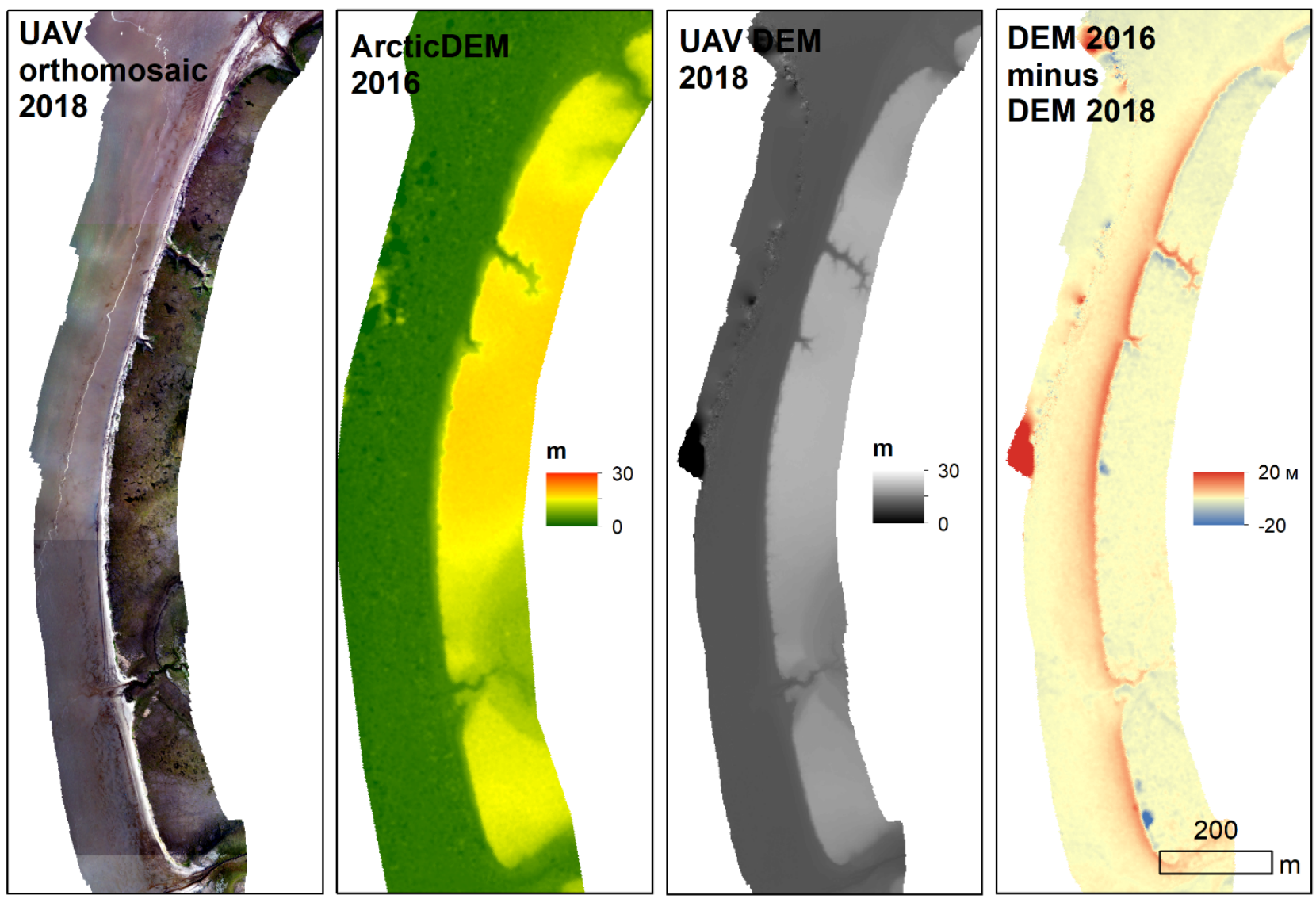

Figure 8. Comparison of the UAV orthomosaic and the DEMs of different years, the area of cape Mutniy (transects 208-239), Yamal key site.

of retreat of other key sites of the Kara Sea (0.5$2.5 \mathrm{~m} / \mathrm{yr}$ [Belova et al., 2017; Kizyakov et al., 2005. Novikova et al., 2018; Vasiliev et al., 2006). It is explained by the exposure of the coasts: the Yamal site is located in the middle part of the shallow Baydaratskaya Bay and is protected by the Marresalskie Koshki islands; Lemberova Bay is located in the Gulf of the Yenisei and is protected by Dikson island and a series of smaller islands. For the Taymyr site, wind-wave and thermal effects are also limited due to more severe climatic conditions: a shorter frost-free period, and, accordingly, a shorter ice-free period, and lower summer temperatures. In addition, the Yamal coast, as well as the coast of the western part of the Kara Sea in general, have more favorable geological conditions for thermoabrasion: unlithified quaternary deposits are widespread, they are often ice-rich and contain tabular and wedge ground ice. On the contrary, at western Taymyr in the Dikson area, rocky shores are more spread, unconsolidated sediments lie in bays only and have a significantly lower thick- ness; their ice content is smaller with no massive ice beds and occasional ice wedges (however, not in Lemberova Bay). Nonetheless, some sections of the two investigated sites experienced fast retreat in certain periods: they retreated at erosional parts, especially in places where wedge ice outcrops, with rates of up to $2 \mathrm{~m} / \mathrm{yr}$, at accumulative parts in the area of the gas pipeline and port construction - up to $10 \mathrm{~m} / \mathrm{yr}$ ).

The coasts of the Yamal key site, as well as the coasts of the western sector of the Kara Sea in general, are highly dynamic, both in areas of prevailing abrasion and in accumulative areas, because of longer ice-free and snow-free period (about 3 months in the Baydaratskaya Bay, compared to about 2 months at Taymyr in the area of Dikson), a warmer climate (the average July temperature in Amderma is $\sim 3$ degrees higher than in Dikson), and the geological structure of the site (loose sediments and more ground ice).

The section of coast at Yamal is much longer $(12 \mathrm{~km})$ compared to the Taymyr key site $(3 \mathrm{~km})$, 
therefore, within it, the coastal abrasion rates vary more (from -3.0 to $+0.7 \mathrm{~m} / \mathrm{yr}$ ) than at Taimyr (from -0.6 to $+0.1 \mathrm{~m} / \mathrm{yr}$ ), however, in general, both areas are characterized by relatively even distribution of rates along the coast, dictated by a rather uniform lithological and geomorphological structure of the studied areas (in comparison, for example, with the Ural coast of Baydaratskaya Bay [Novikova et al., 2018] or Kharasavey [Belova et al., 2020).

Within the Yamal area, the highest rates of retreat (up to $10 \mathrm{~m} / \mathrm{yr}$ ) for the entire observation period (1968-2018) noted within the laida between the cofferdams and the port at the mouth of Yarayakha, that can be explained, above all, by the active development of this area during the construction of the gas pipeline (2009-2013). The construction works implied, in particular, dredging in the port area and excavation of sand from the beach and tidal flat. The vegetation cover on the surface of laida was disturbed by repeated rides of heavy vehicles, which led to the degradation of the ground and active deflation of the sediments. The cofferdams standing out far into the sea disturbed the longshore sediment flux. As a result, the sediments started to deposit to the south of the cofferdams, while to the north, deficiency of sediments provided active erosion of the low terrace in the area of transects 141-146 (Figure 7). In addition, intensive linear retreat within the laida and low terraces could be determined by the fact that low coasts are more easily eroded than high ones (linear retreat rates of high 25-30 m terrace at Yamal site are minimal, however they have high volumetric rates of retreat [Novikova et al., 2018]). High rates of retreat are also associated with areas of wedge ice distribution (in the area of Cape Mutniy and to the south of Yarayakha river).

In the Taymyr peninsula, the maximum rates of retreat (up to $0.6 \mathrm{~m} / \mathrm{yr}$ ) for the study period were noted at short accumulative sections (near the mouths of Lemberova river and an unnamed river in the south of the area). It may be related to the start of erosion of accretion coasts in the recent decades, which is generally typical for some accretion coasts of the Kara Sea and the Arctic in general due to global climate change [Romanenko et al., 2015 Sovershaev et al., 1998. Among the erosional coasts, the maximum retreat was observed in the central part of the territory, where the coast has an abrasional-thermodenudational type and a clear abrasional bluff. It is most likely driven by the NW exposure of this area, which is most influenced by waves from the open Kara Sea. In the northern part of the territory (where the bluff is more gentle and covered by vegetation, and lower retreat rates are observed), the coast is more stable due to the influence of the Lemberova river flow, providing a positive sediment balance. In the southern part of the area, the retreat rates are minimal, because of more resistant bedrock forming the coast.

The increase of retreat rates in the recent period at both key areas (0.6 m/yr in 2016-2018 for the Yamal coast and $0.9 \mathrm{~m} / \mathrm{yr}$ in $2015-2019$ for the Taymyr coast) compared to the historic period (0.5 m/yr in 1968-2016 for Yamal, $0.06 \mathrm{~m} / \mathrm{yr}$ in 1965-2015 for Taymyr) is most likely triggered by a growth of hydrometeorological stress on the arctic coast in the recent decades due to the global climate change (IPCC Special Report on the Ocean and Cryosphere in a Changing Climate, 2019, https: //www.ipcc.ch/srocc/), [Pizhankova, 2016, Shabanova et al., 2018.

\section{Application of UAVs for Arctic Coastal Sureveys}

The use of UAVs for land surveys has a number of advantages compare to other methods of monitoring of coastal dynamics, such as total station surveys, DGPS surveys, or analysis of multitemporal aerial and space images.

- UAVs provide continuous surveys covering relatively large areas, while surveys along transects (with total station/DGPS) are discontinuous in space, i.e., the areas between the transects remain uncovered. UAV surveys are cheaper and more accurate compared to satellite imagery analysis. In the conditions of the tundra, with no tree and shrub vegetation, the use of UAVs for topography surveys is especially relevant.

- Surveying from UAVs is much faster than surveying with a total station and DGPS. A DJI Phantom 4 drone flies about $2 \mathrm{~km}$ of the coast with filming in 30 minutes (battery life) under normal weather conditions. In case of good weather, presence of alternative batteries and a charging source, the survey of the Yamal key site (about $3.6 \mathrm{~km}^{2}$ ) together with DGPS survey along the GCP network can be executed 

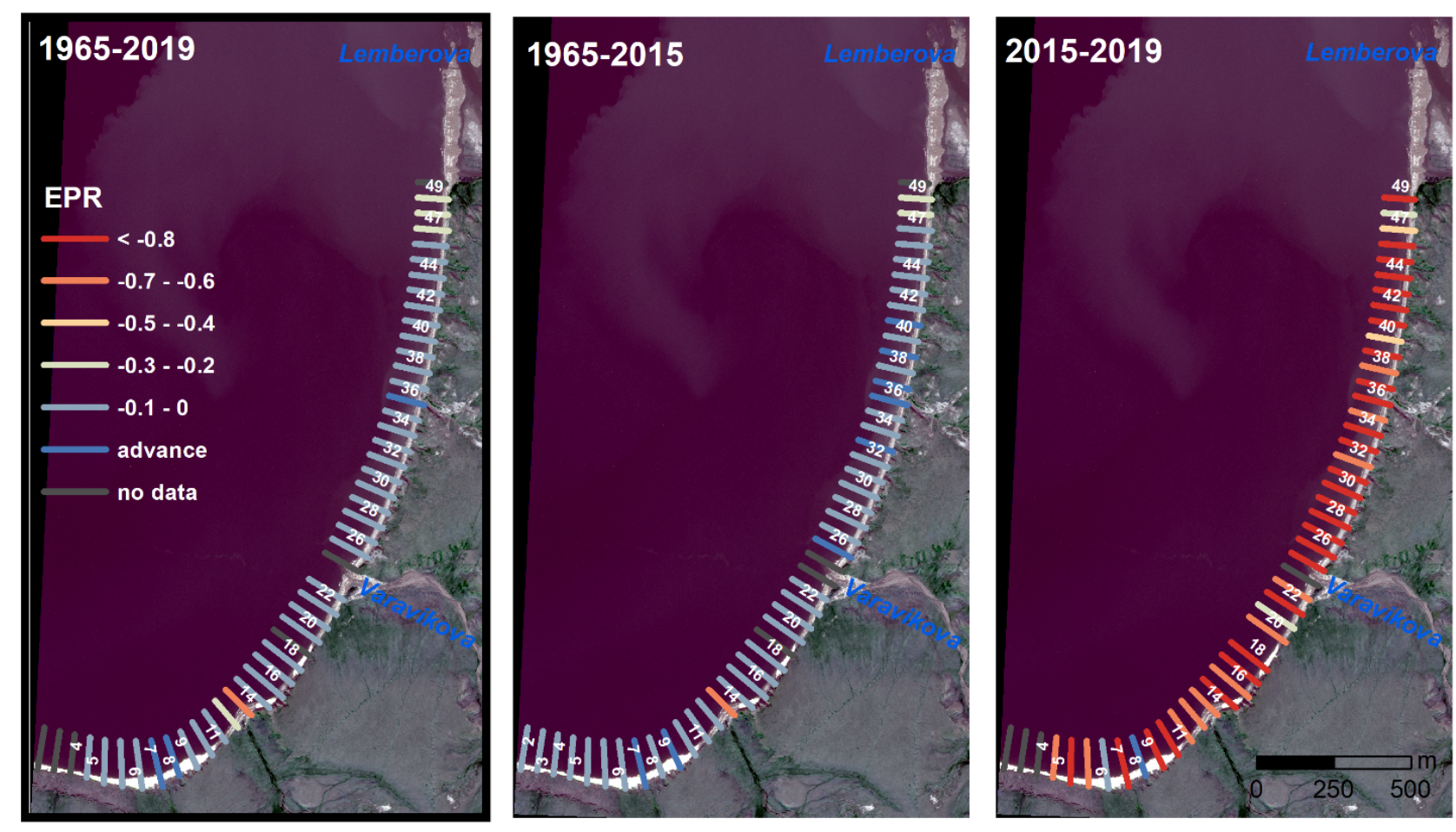

Figure 9. Rates of coastal retreat/advance (EPR) of Taymyr key site.

in 2-2.5 days; the survey of the Taymyr key site (about $0.9 \mathrm{~km}^{2}$ ) takes 0.5 days. Surveys of similar territories by instrumental techniques would take from several days to weeks.

- DEM and orthophotomaps created from UAV imagery and georeferenced by DGPS GCPs have a spatial resolution of $3-5 \mathrm{~cm}$, which is insignificantly poorer than the accuracy of instrumental ground surveys (DGPS - first cms, total station - less than $1 \mathrm{~cm}$ ) and much higher than the resolution of aerial and space imagery ( $0.3 \mathrm{~m}$ and more).

The disadvantages of the technique include:

- limitation by weather conditions: a DJI Phantom 4 PRO cannot operate with wind speed of more than $15 \mathrm{~m} / \mathrm{s}$ and air temperature of less than -10 and more than $+40^{\circ} \mathrm{C}$, during rain, snow or fog;

- limitation of the flight time of one battery for DJI Phantom 4 PRO it is no more than 30 minutes, thus, reserve batteries and a source of electricity for frequent recharging of the device are required.

In general, the UAV method has shown high efficiency for monitoring the dynamics of Arctic coasts. They have considerable potential to be widely used in the future to estimate rates of coastal retreat in the tundra areas. The created DEMs will be compared with the DEMs of previous years (ArcticDEM of the different years, DEMs from aerial photographs, DEMs created from contour maps) and with DEMs by surveys of coming expeditions to reveal the dynamics of the coastal topography and to calculate the volume of eroded, transported and deposited sediments.

\section{Conclusions}

The studied coasts of the Kara Sea had relatively slow retreat for the whole period since the 1960s: $0.4 \mathrm{~m} / \mathrm{yr}$ for the Yamal area and $0.1 \mathrm{~m} / \mathrm{yr}$ for the Taymyr area, which is lower than the average rates of retreat for the whole Arctic $(0.5 \mathrm{~m} / \mathrm{yr}$, [Lantuit et al., 2012) and lower than the average rates of retreat of other key sites of the Kara Sea [Belova et al., 2017, Kizyakov et al., 2005. Novikova et al., 2018. Vasiliev et al., 2006. Such low rates were caused by relatively low vulnerability of the coasts to the wind-wave action (the sites are located in the closed bays and are protected by island chains) and 


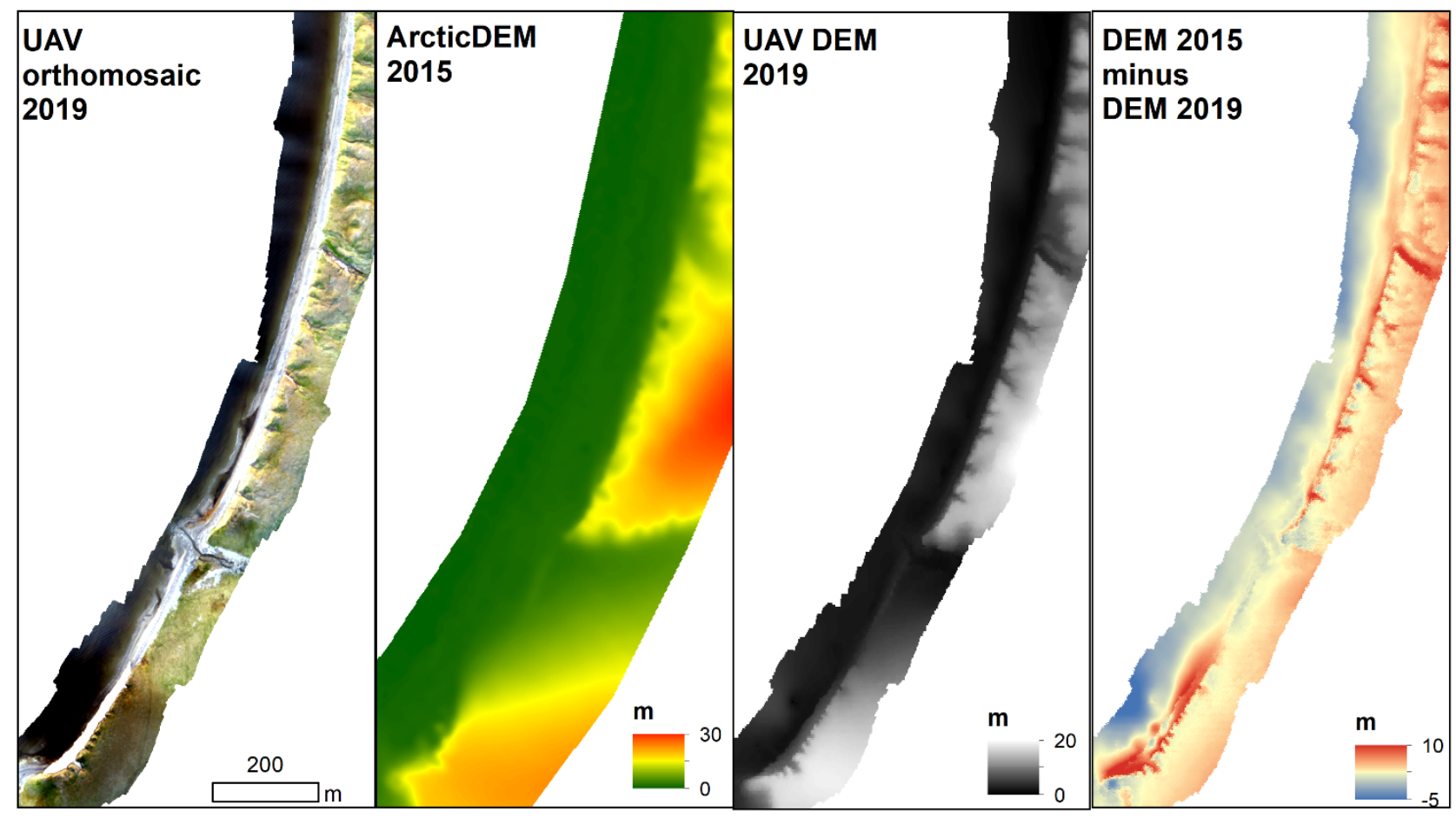

Figure 10. Comparison of the UAV othomosaic and the DEMs of different years, central area (transects 14-38) of Taymyr key site.

by geocryological conditions (absence of massive ice beds, low ice content of the sediments). However, in some places in some periods the rates of retreat of the coasts were high: up to $2 \mathrm{~m} / \mathrm{yr}$ at erosional sections in the areas of ice wedge outcrops, and up to $10 \mathrm{~m} / \mathrm{yr}$ at accumulative sections in the area of gas facilities construction.

The retreat of the coasts of Yamal key site $(0.4 \mathrm{~m} / \mathrm{yr})$ was more intensive than at Taymyr key site $(0.1 \mathrm{~m} / \mathrm{yr})$, because of stronger hydrometeorological forcing in the Yamal area (longer ice-free period, higher temperatures, etc) and more favorable geocryological conditions for thermoabrasion (unlithified sediments and ground ice).

Coastal erosion at both areas showed an increase in the recent period $(0.6 \mathrm{~m} / \mathrm{yr}$ in $2016-2018$ for the Yamal coast and $0.9 \mathrm{~m} / \mathrm{yr}$ in $2015-2019$ for the Taymyr coast) compared to the previous period $(0.5 \mathrm{~m} / \mathrm{yr}$ in $1968-2016$ for Yamal, $0.06 \mathrm{~m} / \mathrm{yr}$ in 1965-2015 for Taymyr), which is most likely triggered by a growth of hydrometeorological stress on the Arctic coast in the recent decades due to the global climate change.

The application of UAVs for coastal dynamics monitoring is efficient and promising. The DEMs created in this study will be compared with the DEMs of previous years (ArcticDEM of the different years, DEMs from aerial photographs, DEMs created from contour maps) and with DEMs by UAV surveys of coming expeditions to reveal the dynamics of the coastal topography and to calculate the volume of eroded, transported and deposited sediments.

Acknowledgments. The study has been supported by the Russian Foundation for Basic Research project No 19-35-90116. A. V. Baranskaya participated in the study with the financial support of the Russian Foundation for Basic Research project No 18-05-60300. A. P. Vergun participated in the study with the financial support of the state scientific program of the Laboratory of Geoecology of the North. We thank Dr. V. Fedosov (Faculty of Biology, Lomonosov Moscow State University), D. Koltysheva (Faculty of Biology, Lomonosov Moscow State University), M. Bondar (Zapovedniki Taymyra), I. Kornienko (Zapovedniki Taymyra) and V. Arkhipov (Zubov State Oceanographic Institute) for the arrangement, logistics and all kinds of support during the fieldworks. 


\section{References}

Atlas of the Oceans (1980), Arctic Ocean, $184 \mathrm{pp}$. GUNIO MO USSR Navy Publ., Moscow.

Belova, N. G. (2014), Massive Ice of the Southwestern Coast of the Kara Sea, 180 pp. MAKS Press, Moscow, Russia. (in Russian, ISBN 978-5317-04875-4)

Belova, N. G., A. V. Novikova, et al. Spatiotemporal variability of coastal retreat rates at Western Yamal Peninsula, Russia, based on remotely sensed data, Global Coastal Issues of 2020. Journal of Coastal Research, Special Issue No. 95, Malvárez, G. and Navas, F. (eds.) p. 367-371, Coconut Creek, Florida. (ISSN 0749-0208)Crossref

Belova, N. G., N. N. Shabanova, S. A. Ogorodov, et al. (2017), Erosion of permafrost coasts of Kara Sea near Kharasavey Cape, Western Yamal, Earth's Cryosphere, 21, No. 6, 73-83, Crossref

Dai, C., I. M. Howat (2017), Measuring lava flows with ArcticDEM: Application to the 2012-2013 eruption of Tolbachik, Kamchatka, Geophysical Research Letters, 44, No. 24, 12-133, Crossref

Dobrovolskiy, A. D., $\quad$ B. S. Zalogin (1982), Seas of the USSR, $192 \mathrm{pp}$. Publishing house of Moscow State University, Moscow.

Eltner, A., P. Baumgart, et al. (2015), Multitemporal UAV data for automatic measurement of rill and interrill erosion on loess soil, Earth Surface Processes and Landforms, 40, No. 6, 741-755, Crossref

Ershova, E. D., (Ed.) (1989), Geocryology of the USSR. Western Siberia, 453 pp. Nedra, Moscow.

Farquharson, L. M., D. H. Mann, et al. (2018), Temporal and spatial variability in coastline response to declining sea-ice in northwest Alaska, Mar. Geol., 404, 71-83, Crossref

GEOS (1997), Baydaratskaya Bay Environmental Conditions. The Basic Results of Studies for the Pipeline "Yamal-Center" Underwater Crossing Design, 432 pp. Publishing House "GEOS", Moscow, Russia. (in Russian, ISBN 5-89118-008-1)

Gonçalves, J. A., R. Henriques (2015), UAV photogrammetry for topographic monitoring of coastal areas, ISPRS J. Photogramm. Remote Sens., 104, 101-111, Crossref

Grosse, G., L. Schirrmeister, et al. (2005), The use of CORONA images in remote sensing of periglacial geomorphology: An illustration from the NE Siberian coast, Permafr. Periglac. Process, 16, 163-172, Crossref

Günther, F., G. Grosse, et al. (2017), Repeat terrestrial LIDAR and DEM-based change detection for quantification of extensive thaw subsidence on yedoma uplands, Abstracts of the International Permafrost Conference "Earth's Cryosphere: Past, Present and Future", Pushchino, Russia, June 4-8, 2017 p. 110-112, FASO, RF. (http://cryosol.ru/im ages/worksfoto/konfe retsii/perm2017tezisy/Abstract S_2017.pdf)
Günther, F., P. P. Overduin, et al. (2015), Observing Muostakh disappear: permafrost thaw subsidence and erosion of a ground-ice-rich island in response to arctic summer warming and sea ice reduction, The Cryosphere, 9, No. 1, 151-178, Crossref Irrgang, A. M., H. Lantuit, et al. (2018), Variability in rates of coastal change along the Yukon coast, 1951 to 2015, J. Geophys. Res. Earth Surf., 123, 779-800, Crossref

Jones, B. M., C. D. Arp, et al. (2009), Increase in the rate and uniformity of coastline erosion in Arctic Alaska, Geophys. Res. Lett., 36, L3503, Crossref Kamalov, A. M., S. A. Ogorodov, et al. (2006), Coastal and seabed morpholithodynamics of Baydaratskaya Bay at the route of gas pipeline crossing, Earth's Cryosphere, 3, 3-14. (in Russian)

Kizyakov, A. I. (2005), Dynamics of termodunadational processes on the coast of Yugora Peninsula, The Cryosphere of the Earth, 9, No. 1, 63. (in Russian)

Kizyakov, A. I., M. V. Zimin, et al. (2013), Thermal denudation, thermal abrasion of sea shores, thermocirques, The Cryosphere of the Earth, 17, 36-47.

Klemas, V. V. (2015), Coastal and environmental remote sensing from unmanned aerial vehicles: An overview, J. Coast. Res., 31, 1260-1267, Crossref

Koci, J., M. V. Zimin, et al. (2017), Assessment of UAV and ground-based structure from motion with multi-view stereo photogrammetry in a gullied savanna catchment, ISPRS International Journal of Geo-Information, 6, No. 11, 328, Crossref

Lantuit, H., D. Atkinson, et al. (2011), Coastal erosion dynamics on the permafrost-dominated Bykovsky Peninsula, north Siberia, 1951-2006, Polar Research, 30, 7341, Crossref

Lantuit, H., P. P. Overduin, et al. (2012), The Arctic Coastal Dynamics database. A new classifcation scheme and statistics on arctic permafrost coastlines, Estuaries and Coasts, 35, 383-400, Crossref Mars, J. C., D. W. Houseknecht (2007), Quantitative remote sensing study indicates doubling of coastal erosion rate in past $50 \mathrm{yr}$ along a segment of the Arctic coast of Alaska, Geology, 35, 583-586, Crossref

Melnikov, V. P., V. I. Spesivtsev, (eds.) (1995), Engineering-Geological and Geocryological Conditions of the Shelf of the Barents and Kara Seas, 195 pp. Nauka, Novosibirsk.

Novikova, A., N. Belova, et al. (2018), Dynamics of permafrost coasts of Baydaratskaya Bay (Kara Sea) based on multi-temporal remote sensing data, Remote Sensing, 10, No. 9, 1481, Crossref

Oblogov, G. E. (2016), Evolution of the cryolithozone of the coast of the Kara Sea during the Late Pleistocene-Holocene, $\mathrm{Ph}$. D. thesis in Geological Science, Institute of the Cryosphere of the Earth, Siberian Department of the Russian Academy of Science, Tyumen. (in Russian)

Obu, J., H. Lantuit, et al. (2016), Relation between planimetric and volumetric measurements of permafrost coast erosion: a case study from Herschel 
Island, western Canadian Arctic, Polar Research, 35, No. 1, 30313, Crossref

Ogorodov, S. A. (2005), Human impacts on coastal stability in the Pechora Sea, Geo-Marine Letters, 25, No. 2-3, 190-195, Crossref

Ogorodov, S. A., A. V. Baranskaya, et al. (2016), Coastal Dynamics of the Pechora and Kara Seas Under Changing Climatic Conditions and Human Disturbances, Geogr. Environ. Sustain., 3, 53-73, Crossref

Pizhankova, E. I. (2016), Modern climate change at high latitudes and its influence on the coastal dynamics of the Dmitriy Laptev Strait area, Earth's Cryosphere, 20, No. 14, 46-59.

Pizhankova, E. I., M. S. Dobrynina (2010), Remote sensing data, coastal dynamics, ice complex, alas complex, thermal abrasion, thermal denudation, Dynamics, 14, No. 4, 66-79.

Romanenko, F. A. (2011), Geomorphological types of low coasts of Yamal and Tazovskiy peninsula and their role in forming of shore deposition, Geology of Marine and Oceans, Proceedings of the XIX International Conference on Marine Geology, 14-18 November 2011, 1 p. 75-79, Publishing House "GEOS", Moscow, Russia. (in Russian)

Romanenko, F., A. Baranskaya, et al. (2015), Lowlying coasts of the western arctic seas: origin, age and modern dynamics, Voprosi Geografii, 140, 275-306. (in Russian)

Romanenko, F., E. Garankina, O. Shilova (2009), The stratigraphy of recent sediments at western Yamal Peninsula and topography formation in Late Pleistocene and Holocene, Fundamental Problems of Quaternary: Results and Trends of Further Researches. Proceedings of the 6th All-Russian Quaternary Conference, Novosibirsk, Russia, 19-23 October 2009 p. 505-508, Publishing House of Siberian Branch of the Russian Academy of Sciences, Novosibirsk, Russia. (in Russian)

Shabanova, N., S. Ogorodov, et al. (2018), Hydrometeorological forcing of Western Russian Arctic coastal dynamics: XX-century history and current state, Geogr. Environ. Sustain., 11, 113-129, Crossref

Smith, M. W., D. Vericat (2015), From experimental plots to experimental landscapes: topography, erosion and deposition in sub-humid badlands from structure-from-motion photogrammetry, Earth Surface Processes and Landforms, 40, No. 12, 1656 1671, Crossref

Sovershaev, V., K. Voskresensky, et al. Development of coastal accumulative forms in permafrost conditions, Dynamics of the Arctic coasts of Russia p. 80-92, Moscow State University, Moscow.

Streletskaya, I. D., A. A. Vasiliev, et al. (2009), Erosion of sediment and organic carbon from the Kara Sea coast, Arctic, Antarctic, and Alpine Research, 41, No. 1, 79-87, Crossref

Thieler, E. R., E. A. Himmelstoss, et al. (2009), Digital Shoreline Analysis System (DSAS) version 4.0, An ArcGIS Extension for Calculating Shoreline Change, Open-File Report 2008-1278, U.S. Geological Survey, U.S. (https://pubs.er.usgs.gov/publication /ofr20081278,Crossref

Trofimov, V. T., Yu. B. Badu, Yu. K. Vasilchuk (1986), Geotechnical Conditions of the Gydan Peninsula, 212 pp. Publishing House of Moscow State University, Moscow.

Vasiliev, A. A., I. D. Streletskaya, et al. (2006), Coastal dynamics of the Kara Sea, Earth's Cryosphere, 10, No. 2, 56-67.

VNIIOkeangeologiya (2000), State Geological Map M 1:1,000,000, 1st edition, sheet S44 pp. VNIIOkeangeologiya, Russia.

Corresponding author:

A. V. Novikova, Lomonosov Moscow State University, Moscow, Russia. (annamsu17@gmail.com) 